\title{
Linking Foreign Direct Investment and Economic Development in Sierra Leone
}

\author{
Ezekiel K. Duramany-Lakkoh¹, Abubakarr Jalloh², Mohamed Sajor Jalloh ${ }^{3}$ \\ ${ }^{1}$ Faculty of Management Science, Institute of Public Administration and Management (IPAM), University of Sierra Leone, \\ Freetown, Sierra Leone \\ ${ }^{2}$ Department of Banking and Finance, Institute of Public Administration and Management (IPAM), University of Sierra Leone, \\ Freetown, Sierra Leone \\ ${ }^{3}$ Department of Accountancy, Institute of Public Administration and Management (IPAM), University of Sierra Leone, Freetown, \\ Sierra Leone \\ Email: Ezekiel.duramany-lakkoh@fulbrightmail.org, bakarrjaz@gmail.com,mohamedsajorj@gmail.com
}

How to cite this paper: Duramany-Lakkoh, E.K., Jalloh, A. and Jalloh, M.S. (2022) Linking Foreign Direct Investment and Economic Development in Sierra Leone. Journal of Mathematical Finance, 12, 105-125. https://doi.org/10.4236/jmf.2022.121007

Received: October 7, 2021

Accepted: February 8, 2022

Published: February 11, 2022

Copyright $\odot 2022$ by author(s) and Scientific Research Publishing Inc. This work is licensed under the Creative Commons Attribution International License (CC BY 4.0).

http://creativecommons.org/licenses/by/4.0/

(c) (i) Open Access

\begin{abstract}
Foreign direct investment (FDI) is considered in the literature as an essential driver of economic growth. This paper aims to investigate the impact of FDI on economic growth of Sierra Leone economy. As a whole, the period under consideration is a thirty-seven year period spanning from 1980 to 2016. Most researchers conclude that there is a positive impact of FDI on Economic Growth of a nation's economy, but in this paper, we discovered that FDI has no relationship with economic growth in Sierra Leone. Empirical methods were used to analyze data and results are based on regression analysis conducted from available data. This paper ascertains that FDI (stock) inflow in Sierra Leone has no impact on the economic growth of the nation.
\end{abstract}

\section{Keywords}

Foreign Direct Investment, Manufacturing Sector in Sierra Leone, Economic Development, Private Investment

\section{Introduction}

\subsection{Overview of the Study}

FDI is expected to have an impact on the growth of an economy of a country, and this impact is expected to be positive and significant [1], although not in all cases. Sierra Leone is a developing country that depends on foreign direct investment and foreign aid to support economic activities, even when the country has vast deposits of minerals like iron ore, rutile, diamonds and vast fertile land 
for agricultural purpose. Duramany-Lakkoh (2020) [2] argues that FDI inflow in a country creates opportunities in employment, exports of goods and services from host country as well as strengthen the financial institutions and capital flow within the country. The role of FDI in the development of multinational and domestic or local industries improvement for export promotion and employment creation cannot be overemphasized in poor and developing countries with a vast deposit of minerals like Sierra Leone. FDI is a significant source of capital and resource inflow particularly for countries in which spillover of technology and advanced production techniques are required to aid local industries to improve and become more productive [2]. In recent years Sierra Leone has also depended on foreign aid to finance its economic activities and national budget deficits, though it has a vast deposit of minerals and fertile land for agricultural purposes [3].

This study covers a thirty-seven-year period, from 1980 to 2016 and uses descriptive and empirical methods for data collection and analyses; different econometric models were used to evaluate how FDI impacts economic growth in Sierra Leone. Data collected is from various reliable sources such as the World Bank database, world development index, the United Nations conference on trade and development, the United Nations educational scientific and cultural organization, Bank of Sierra Leone (BSL) database, the Ministry of Finance and Economic Development Sierra Leone.

\subsection{The Motivation of the Study}

As stated earlier, FDI is an essential element and one of the significant factors in the development of a country's economy, and its impact is expected to have a positive effect on economic growth. As such it is worth examining if FDI inflow did have contributions to the development of Sierra Leone economy. The countries financial systems have seen an increased number of international financial institutions in conventional banking and microfinance [3], with a focus to promote trade and discourage aid. For the past two decades, the country has seen the establishment of many multinational companies such as Vimetco N.V from the Netherlands, a subsidiary of Sierra mineral Holdings Ltd which is investing in Bauxite mining. The African Mineral Ltd (AML) from the United Kingdom and Shandong Iron Steel (SD steel) from China having jointed operation in the Tonkolili Iron ore project. The Sierra Rutile Ltd from the United Kingdom invests in Titanium and Zirconium mining, and the BSG Resources Ltd also from the United Kingdom involved in Diamond mining [4]. Socfin Agricultural Company Sierra Leone Ltd invests in Oil Palm Plantation, the Telecommunication sector, the fisheries industry, the tourism sectors and others. It is worth examining what impact these multinational companies and corporations have created in the country's economy. From this, we can say the primary aim of this paper is to assess whether FDI inflow has an impact on economic growth and how significant is this impact on the development of the Sierra Leone economy. 


\section{Literature Review}

\subsection{Theoretical Literature}

\subsubsection{The Concept of Foreign Direct Investment}

While FDI in recent years has become a global phenomenon, enterprises and institutions are now striving more toward globalization. With this, the topic of FDI has relatively been vital and worth discussing, especially the perspective of enterprises seeking resources, accessing cheap labor, research, and development, the marketing and distribution of products for expansion and domination of competitor and seeking new markets environments. Due to its global phenomenon, there are various definitions and concepts about the meaning of FDI. The International Monetary Fund, (1993) [5], refers to FDI as an investment that is made to acquire lasting interest in an enterprise operating outside the country of the investor. In this case, the purpose of the investment is to gain a voice in the management of the enterprise by the investor. According to the OEDC benchmark (1996) [6] direct investment is when a single foreign investor, incorporated or unincorporated, owns $10 \%$ of ordinary shares and/or voting power of an enterprise in a host country, which means, it cannot be classified as FDI if the investor doesn't have an effective voice in the management of the enterprise. Effective voice control here implies that the investors are able to influence management of the enterprise and does not mean they have absolute control of the enterprise. The primary distinction between FDI and portfolio management is the intention to exercise control over the enterprise. The foreign enterprise, group or entity that makes such investment is called the "direct investor" and the enterprise.

On the other hand, Horizontal FDI is when an enterprise invest in a foreign country in the form of carrying similar production activities carried in the home country, this is usually done within the same industry as that which the enterprise operate in the home country. FDI can be classified depending on various criteria, some common classifications include:

FDI classification base in the direction of investment, this can either be inward or outward. Inward FDI is when a foreign firm takes control of domestic shares, assets and/or voice in management abroad. Outward FDI is when a local firm takes control of foreign enterprise shares, a voice in management or assets.

FDI can be classified on the bases of investment objectives. It is essential to know that these objectives vary from time to time and enterprise to enterprise base on their activities. Some of the main types of investments include resource seeking, knowledge seeking, efficiency seeking and market seeking. In resource seeking objective, the enterprise goes abroad to find a cheap source of supply of well-motivated labor, skilled and unskilled, move to areas where it is close to raw materials in other to gain technological capabilities, organizational skills, and marketing expertise. The knowledge seeking objective is similar to the resourceseeking perspective only that in the knowledge-seeking objective, the enterprise aims is to acquire new competitive advantages or positioning in certain geo- 
graphical or products markets. In an efficiency seeking, the objective of the enterprise is to rationalize established production units in other to benefit from standard economic activities in different geographical locations. The primary objective here is to advantage of economies of scale and scope in relevant essential investment areas in foreign markets. This objective comes after the market-seeking, or resource-seeking objectives are being realized. Market-seeking goal is aimed to serve demand in national, regional and international markets by the export of products. This form of FDI is usually motivated by the relatively low production and export cost, free trade barriers, the need to stay close to customers and globalization of the world economy. FDI classification base entry mode can either be Greenfield or mergers and acquisition. Greenfield investment is a direct investment that focuses on the expansion of existing facilities or the creation of new facilities abroad. This form of investment is the primary target of host nations since it promotes efforts in creating production capabilities, transfer of know-how and technologies, the creation of new jobs and linkage of global markets skills and ideas. Greenfield investments take the form of assembling all elements of the production process from scratch, and also an entry mode which interacts with ownership strategies, wholly owned or joint venture. The benefit of Greenfield investment to national economies is the creation of jobs, advanced methods of research and development by introducing new technologies and increase in capital investment. Some of the demerits of this form of investment are profit generated does not reflect on national economies, crowding out of domestic enterprises and loss of market share for local enterprises [6].

Mergers and acquisitions (M\&A) is a primary form of FDI where a domestic enterprise's asset is transferred to foreign firms. M\&A usually takes two ways, firstly, cross-border mergers which occurs when domestic enterprise assets and operations are combined with foreign enterprises operations to establish a new entity that is legally binding. Secondly, cross-border acquisitions occur when a domestic enterprise's assets and operations are transferred entirely to a foreign enterprise, with the domestic enterprise becoming a subsidiary of the foreign enterprise. This idea was developed by Raymond Vernon (1979) [7] in his hypothesis of the product lifecycle. According to Raymond [7], the foreign enterprise invests to gain access to cheaper factors of production. This form of investment is encouraged by the domestic government if it is export-oriented and posse's technology, technical and managerial know-how that is needed or not available in the domestic industry or country. M\&A is most common and preferred ways for multinationals to engage in FDI than Greenfield investment.

\subsubsection{Concept of Economic Growth}

Economic growth is referred to how much more an economy of a country produces in a period compared to the past. In general, economic growth is the measure of how much an economy's output or production during a particular year or period compared to its past. This comparison must remove the effects of inflation; economic growth is usually measured in gross domestic Products (GDP) or 
gross national products (GNP). GDP is referred to the total market value of total production of goods and provision of services in a particular year or quarter. GDP usually includes all government spending, consumers' consumption, and investment spending plus total net export. GNP is the total market value of total production of good and provision of services by a country's domestic residents. GNP is said to include all domestic resident earnings from the production of goods, provision of services and investment outside the country. The main difference between GDP and GNP is that GDP does not take into account any earnings of its domestic resident outside the country but considers all earnings from foreigners residing in the country. While GNP considers and take into account all earnings of local residents outside the country but does not include earnings from foreign residents, who are staying in the country. For this reason, we will measure economic growth base on GDP [8].

\subsubsection{Endogenous and Exogenous Growth Model}

The exogenous growth model is also known as the Solow-Swan growth model and an extension of the Domar, (1946) [9] which include a new term that is referred to productivity growth. This model state that an increase in the savings rate will lead to an increasing rate of economic growth and at the same time will increase the use of capital stock in relation to output; in brief, this will lead to a reduction of production or output generated by additional capital. This model converges in growth on the basis that rich countries will always grow slower than poor or emerging countries [10]. Endogenous growth theory holds that growth is primarily as a result of external forces in the economy, which can occur as a result of investment in human capital, innovation, and knowledge. In this case, the endogenous growth model states that the long run growth rate of the economy will depend on policy implementation in the economy. In general, the fundamental difference between the two is that the exogenous growth model uses the neoclassical production function with decreasing in productivity of factors of production, while in the endogenous growth model, the productivity of factors of production is at least constant.

Heinz and Neri (2014) [11] stated that from Adam Smith classical approach in considering the problem of economic growth down to David Richardo [12], Malthus T. R [13], and Karl Marx [14], is not a phenomenon. This conclusion saw both equilibrium, and the actual rate of capital accumulation, equilibrium and actual growth rate of output as a whole were seen to depend endogenously on agents' behavior. This idea is not new under economic growth consideration. According to Lukasz (2014) [10], economic growth is based on two strong beliefs. Firstly, the Schumpeter's theory [15], which states that economic growth is unbalanced and thus depend on innovation, and the Lewis theory and Rostow theory [16] which predicts economic growth will balance in the long-run even if it is unbalanced in the short-run. The relationship between FDI and economic growth has been subject to numerous research studies in recent years, and some these include Xuan-vinh \& Jonathan (2006) [17], Mohammad \& Mohmoud (2014) 
[18], Duramany-Lakkoh et al. (2021) [19], Elboiashi (2011) [20], Heinz \&Neri (2014) [11]. As expected, FDI has some positive impacts on economic growth based on conclusions from, Landry C. (2015) [21]; Semwanga (2011) [22]; Ovat [23]; Adeleke, Olewe and Fesesin (2014) [24], they pointed out that there is a positive relationship between the two. But according to other researchers, this is not always the case, Nigh (1986) [25] stated that there is a negative relation between FDI and economic growth. Mohnen (2001) [26], Wang (2009) [27], also concludes from their research that there is no connection between the two based on variables they considered. FDI stimulated with the inflow of capital can thus create opportunities for employment, infrastructural development, transfer of knowledge spillover and the creation of businesses or companies in the host country.

The negative part of FDI to domestic companies is that they crowd out some of these domestics companies or businesses because of their large stock of capital. For instance, most of the local or domestic mining companies stopped operations in the country with the coming of large multinationals like African Minerals, and in the telecommunication industry. Datatel never made it in the market and had to close operation because it didn't have the stock of capital to compete with major multinationals like Airtel and Africell. It can also observe that the former national telephone operator in the country (Sierratel) is struggling to stand competition from these companies.

\subsection{Empirical Literature}

There is a growing interest in the investigation of the relationship between FDI and economic growth around the world. The ever-increasing literature in this field of study varies across countries and various sectors. Below is a highlight of some findings different countries, industries and sectors.

Gui-Diby S. L. (2014) [28] analyzed the impact of FDI on economic growth in Africa using panel data analyses for 50 countries for the period from 1980 to 2009. His findings indicate that FDI inflows had a significant impact on economic growth in the region during the whole period. He found that the low level of human resources had not limited the effects of FDI on economic growth, but when he considered the period in two folds; firstly from 1980 to 1994, he discovered that there was a negative impact and secondly from 1995 to 2009 FDI had a positive impact on economic growth.

Khaliq A. and Noy I. (2007) [29], analyzed the effectiveness of FDI by considered 12 sectors in the economy of Indonesia and they discovered that FDI had a positive impact on the economy as a whole. But taking their observation further, sector by sector, they pointed out that sectors in the mining and extractive area showed a negative impact.

Adewumi S. (2006) [30] investigated the impact of FDI in 11 developing countries in Africa from 1970-2003 using regression analysis by taking economic growth as the dependent variable, he found out that FDI is positive in countries 
like Benin, Botswana, Burkina Faso, Central African Republic, Egypt, Mali, and Nigeria. It was only in Angola that FDI had a positive and significant effect on economic growth. But countries like Cote d' Ivoire, South Africa, and Tunisia showed a negative impact of FDI on economic growth.

Akinlo (2004) [31] analyzed the impact of FDI on economic growth in Nigeria for the period 1970 to 2001, by using ECM, the result shows that FDI has a statistically insignificant effect on economic growth. A significant reason for this was due to the argument that most of the FDI in the country was concentrated in the extractive sector (oil) which is not much growth enhancing when compared to the other areas like the manufacturing sector etc.

Chabe L. (2015) [32] analyzed the impact of FDI on the economic growth of Cameroon for the period between 1977 and 2010. He concluded that there was a positive impact in the overall growth, but when he analyzed sector by sector, he found that the effectiveness of FDI in the manufacturing sector was negative while there was a positive effect on the service sector.

\section{Sierra Leone Economy since Independent}

In the 1960s, Sierra Leone as a country was already well known around the world because of it diversifies the range of natural resource including diamond, bauxite, and iron ore, vast land for agriculture, tourism and marine resources. During the 60s the economy grew about 4 percent (Sierra Leone economic record, 2010) [33]; this was mainly due to agricultural production, mining activities, stable currency in the currency market, export growth and positive currency reserve. In the 70s, the country experienced some economic difficulties, some the reasons for this were the closure of the Marampa mine which was one the country's leading mining operator, oil price shocks combined with high inflation and depreciation of the Leones, overall growth decreased by around 1.6\% during the late 70s. Economic growth continued to decline during the 80s; macroeconomic factors were unstable due lack of government recovery policies. As a result, the country experienced low per capita income, more than three-fourth of the population were living under poverty line, domestic revenue was adverse to GDP. In other to recover this economic downturn, the government decided to initiate several economic programs which were ineffective. During the 1980s, FDI net inflow decreases to its lowest at US\$-140.3 million in 1986. Inflation rate continues to increase while national currency reserves declined (inflation was at its highest in 1987 at 165\% (annual percent of GDP deflator), Reserves was at its lowest in 1981 with a deficit of US\$-1.023 (billion). These combined with mismanagement of state wealth and bad or lousy governance, citizens were no longer able to handle the hardship which leads to disruptions and eventually to the civil war in the early 1990s that spanned more than ten years, displacing more than half the population at the time. This civil war resulted in the loss of lives, destruction of properties, social and physical infrastructures, abandonment of agricultural farm, illegal mining activities, destruction of manufacturing facil- 
ities and service sector. All this aggregated to worsening the economic situation of the 90s to 2000. See graphs below. Figure 1 below shows the GDP growth of Sierra Leone as a percentage from 1962 to 2000, while Figure 2 shows GDP growth from 2000 to 2016 . This shows that the economy picked up significantly above $10 \%$ after 2002 , this was immediately after the civil war.

In March 1991 the war started in the South-East part of the country where it bordered with Liberia. All mining operations were at a halt, and agricultural farms were abandoned. As a result, by the end of 1992, GDP was at its lowest ever declining by $-19 \%$ [34], the Leones continued to depreciate against the USD and other international currencies throughout this period the country currency deserve were negative. The country was at its worst during the periods between 1997 to 1999 and overall GDP per capita declined from US\$180 in 1992 to US\$151 in 1999 (world data atlas-Sierra Leone, 2017). Export during this period was also unstable, falling from US\$197.4 in 1992 to reach its lowest in 1999 with a value of US $\$ 28.6$ million and importation of goods was hits it lowest ever in 1999 at US\$86.8 million (Source: data from world data atlas-Sierra Leone, 2017, computed by authors) [34].

The economy strongly recovered immediately after the war, GDP grew at an average of $16.8 \%$ during the period between 2000 to 2003, during the period of 2008 to 2009, international price for iron ore and the world financial crisis adversely continued to affect the economy, growth rate of GDP slowed down in 2008 by $5.5 \%$ and further down in 2009 by and $4.6 \%$ although this low rate was higher than Sub-Sahara average which was $2 \%$.

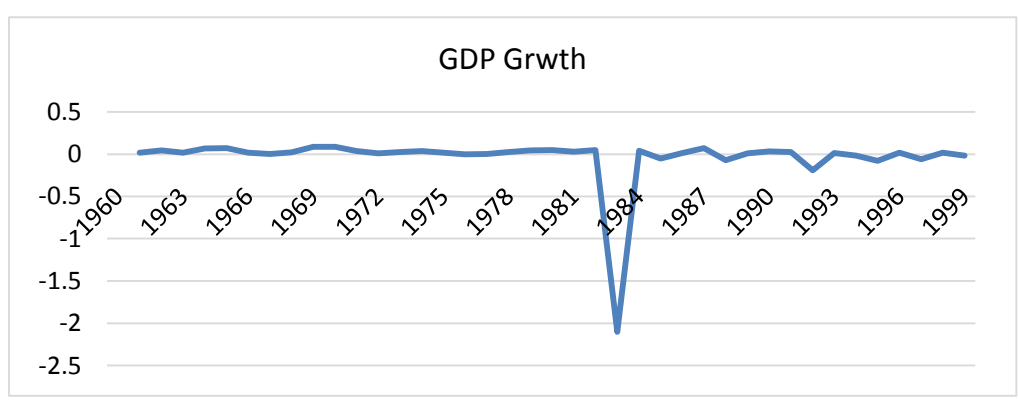

Figure 1. GDP growth as in percentage from the period of 1960 to 2000. Source: World Bank data (computed by authors).

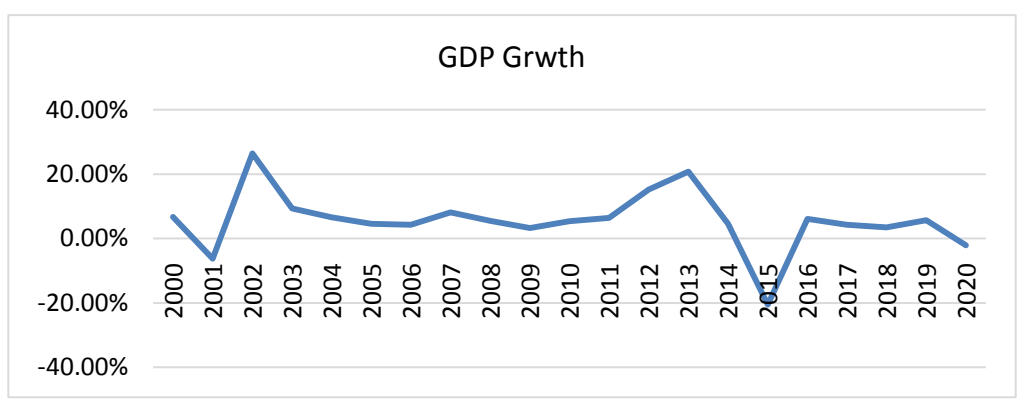

Figure 2. GDP growth as a percentage from the period of 2000 to 2016. Source: World Bank data (computed by authors). 
With the fall of iron ore price, the country dependency on the export of this and other minerals to generate foreign currency was much affected, which caused the national currency to depreciate. With the world economy recovering from the financial crisis, the economy of Sierra Leone also improved in 2012 by $15.18 \%$ and grew by $20.7 \%$ in 2013 . This growth didn't last long as it crippled down to $4.56 \%$ in 2014 and further down to $-20.49 \%$ with the outbreak of the deadly Ebola epidemic in 2014 which claimed the lives of nearly more than 4000 people across the country. Inflation was at minimal during this period and showed improvement from $73.55 \%$ in 2001 to $1.79 \%$ by 2014 but later rose to $19.63 \%$ by the end of 2015 . The national currency against the US dollar has seen a steady increase from SLE 1986.00 per US Dollar in 2001 on average to SLE 5080.00 per US Dollar on average by the end of 2015, and it is on the rise (Source: data from world data atlas-Sierra Leone, 2017, computed by authors) [34].

Since the end of the civil war in 2002, growth rate peaked at $20.7 \%$ in 2013 (World Development Indicators, 2017 [35]; African economic outlook, 2017) [36]. Sierra Leone also saw double-digit gross domestic product of $15.8 \%$ in 2012; this was mainly due to the boom in the extraction and exportation of iron ore and investment of government into infrastructural development and agricultural funding. However, this growth rate was disrupted with the decline in the price of iron ore and the outbreak of the Ebola epidemic in 2014; the IMF projected a $\$ 4.289$ billion Nominal Gross Domestic Product for 2016. The economy quickly recovered from the decline of iron ore prices and the eradication of the Ebola epidemic with the help of the international community. The economy saw an improvement in the recovery of a real gross domestic product from a negative of $-21.1 \%$ in 2015 to a positive GDP of $6.06 \%$ in 2016 . Sierra Leone is now seen as one of Africa most significant countries for business opportunities as it is now less dependent in iron ore mining by switching attention to agricultural funding and improvement, infrastructural development, tourism sector and fishery industry.

\subsection{Foreign Direct Investment in Sierra Leone}

Sierra Leone, a country reach in mineral resources such as gold, diamond, bauxite and iron ore, and so forth, has attracted little FDI since gaining independence from the British since 1961, this is due to political instability such as the civil war in the 1990s and socio-economic problems. Sierra Leone has little or no outward FDI but has been able to attract investor around the globe. The country saw a steady net inflow of FDI during the 70s, from around US\$8.2 million in 1970 to almost twice this figure by the end of 1979 (US $\$ 16.1$ million). This flow did not reflect an increase regarding percentage in GDP (decreased from 1.89\% to 1.45\% in 1970 to 1979 respectively). By the end of 1980 , the country saw a negative net inflow of US\$-18.6 million though it had an FDI Stock inflow of more than US $\$ 323$ million during that year [35]. Moreover, by the end of 1986, this deficit net inflow has risen to US\$-140 million ( $-28.62 \%$ of GDP). The country was merely able to attract FDI inflow during the 80s; henceforth the country expe- 
rienced less investment, but by 1990 the country was able to maintain a positive net inflow of US $\$ 32.4$ million (4.99\% of GDP). This change was as a result of investors being able to find appropriate investment for their funds and less repatriation or closure of existing enterprises occurred during this period. It was surprising from observation to see that during the war, the country had a steady FDI inflow (stock) at an average of US $\$ 240$ million throughout the 1990s (an average of $0.5 \%$ to GDP) [35].

After the war, the country attracted investment in the mining, agriculture, and infrastructure which saw a rapid increase in FDI net inflow from around US $\$ 39$ million in 2000 to US $\$ 238$ million (9.11\% of GDP) by 2010. Information on foreign direct investment in millions of United States Dollars is shown in Table 1 below. During this same period, FDI inward (stock) increased fromUS $\$ 1,361$ billion in 2010 to 2.108.4 in 2016. During this period, the country saw rapid development in its financial system, infrastructural improvement, and its service sector. The world economic crisis in 2008 had some adverse effects both in attracting foreign investment and economic growth, although the country saw a quick recovery and by the end of 2011, FDI net inflow was about $32.3 \%$ of GDP. Economic growth and FDI inflow were severely affected by the Ebola epidemic outbreak in 2014, and during this period the country experienced it lowest FDI inward (stock) and net inflows since 2010. As a result, after the country was declared Ebola Free, the country's Minister of Foreign Affairs went to various conferences around the world including London (Attracting investment back to post-Ebola Sierra Leone) to attract investors. In these conferences, he made it clear that the government has placed its priorities on the infrastructure sector, Agricultural industry, and mining sector. As expected, the country recovered quickly to high record figures with FDI net inflow and Inward stock of about US $\$ 510$ million and US $\$ 2.108$ billion respectively by the end of 2016 [35].

The country's substantial mineral deposits, an absence of any outright discrimination against foreign investors, companies, and regulations on repatriation of profit, sales of assets also guaranteed in the new investment code makes the country very attractive for FDI. The slow legal system in business setup and high level of corruption, lack of infrastructure, political violence and social upset due to socio-economic disturbances and lack of skilled labor are some of the major hindrances to maintain foreign investment in the country. With all these obstacles, Sierra Leone is ranked 148th out of 190 countries according to the World Bank's doing business report (2017) [37].

Table 1. Foreign direct investment 2010-2016.

\begin{tabular}{ccccccccc}
\hline Foreign Direct Investment & $\mathbf{2 0 1 0}$ & $\mathbf{2 0 1 1}$ & $\mathbf{2 0 1 2}$ & $\mathbf{2 0 1 3}$ & $\mathbf{2 0 1 4}$ & $\mathbf{2 0 1 5}$ & $\mathbf{2 0 1 6}$ \\
\hline FDI inward flow (Million USD) & 238 & 950 & 722 & 430 & 404 & 263 & 516 \\
FDI Stock (Million USD) & 1361.1 & 1310.7 & 1417.4 & 925.5 & 1329.4 & 1592.4 & 2108.4 \\
FDI Inward (\% of GFCF) & 30.11 & 77.76 & 76.87 & 62.77 & 66.37 & 44.09 & 80.5 \\
FDI Stock (\% of GDP) & 52.80 & 44.54 & 37.28 & 18.81 & 26.51 & 35.52 & 53.59 \\
\hline
\end{tabular}

Source: unctadstat (2017). 
Sierra Leone has increasingly attracted investment from China. The two countries have an agreement to financing the country's new airport at Hastings, construction hospitals, roads, and a hydroelectric dam. China Hainan Rubber Group (CHRG) has also invested in a rubber production project and rice cultivation that worth's $\$ 1.2$ billion and Kingho Group have an investment worth around \$6 billion in mining [38]. In 2016, Chinese investors have targeted the mining, transportation and infrastructure sector. In 2016, the government of Sierra Leone reached an agreement with Bollore Group (subsidiary from France) on the management of the Freetown Port Terminal (FPT), one of the world largest natural harbours. This agreement includes the construction of a new dock worth around $\$ 120$ million and infrastructures worth around \$87 million [36]. Companies like the Sierra Diamond Group, based in the United States also announced future investment in new mining activities worth about $\$ 25$ million in the next few years. Sierra Leone is also attracting investment from Turkey, Belgium, Germany, Senegal, and so forth. Table 1 above shows foreign direct investment variables in Sierra Leone from 2010 to 2016.

\subsection{Foreign Direct Investment and Gross Domestic Product}

From Figure 3 below, we see that the two variables are not moving at the same rate or in the same direction, which suggests that FDI (stock) inward is not a significant determinant of GDP growth in Sierra Leone. This relationship is not unique for a developing country like Sierra Leone due to its vast deposit of mineral resources, although it has been plagued with political and civil unrest throughout the last three decades of the twentieth century. Taking a closer look at the above graph, we can see that the two variables are less volatile, except for FDI during the periods of 2007 to 2011. In comparing the volatility between the two variables, we can see that FDI is more volatile. For instance, GDP fluctuated between $-30 \%$ (in 1986 and 1990) to $60 \%$ in 1988, and this was just before the escalation of the civil war in the 90 s.

As for FDI, it increased from $-60 \%$ in 2008 during the world financial crisis to $380 \%$ the following year (2009) because of the vast investment in the mining of Iron Ore by African Minerals Ltd (AML) and other companies. Both variables

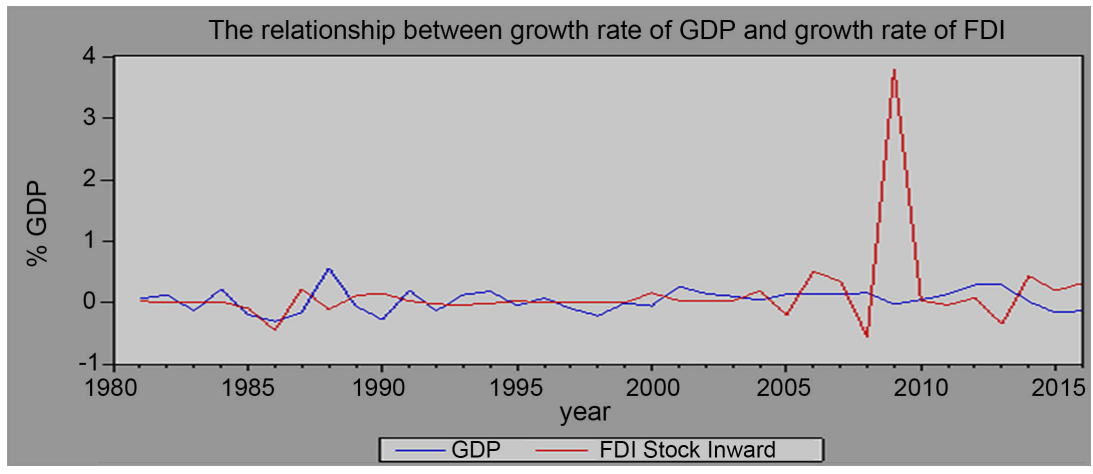

Figure 3. Relationship between growth rate of GDP and growth rate of FDI. Source: unctadstat (2017). 
are also not moving in the same magnitude, for instance, in 1988 GDP increased by $60 \%$ while at the same period FDI decreased by $-10 \%$. It is observed that throughout the periods of 1991 to 1999, there was almost no FDI inflow fluctuation, while GDP growth rate fluctuated from $-30 \%$ to $20 \%$ to $-10 \%$ and to $20 \%$ again (in 1990, 91, 92 and 1994 respectively). The highest increase in FDI was $380 \%$ in 2009 which drastically decrease in 2010 and during this period GDP dropped from $2 \%$ to $0 \%$ and showed a slit recovery the following year. We should note that the above only shows the relationship between the two variables and not the contribution of FDI to economic growth. This direction and strength of this relationship can be illustrated using scatter plots.

Table 2 below provides information on changes in FDI and other important economic indicators from 2006 to 2015. Table 2 below shows that while FDI increases by $631 \%$, remittances and other official flows also increases significantly, showing that the country also benefited from huge external assistance for reforms and capacity building within sectors.

\section{Data and Methodology}

In this chapter, we will highlight the framework in which we conducted the research, and we will also identify data sources, specify the model we used, and the presentation of estimated techniques and their analysis.

There is no specific explanation on how economic growth can be modeled within the framework for a regression [17]. As a result, there is no clear guide as to what variables can be appropriate to include in determining economic growth when specifying a regression equation.

\subsection{Data}

This study considers secondary data published from various reliable sources; this includes national institutions such the Bank of Sierra Leone (BSL) annual reports, statistical information and bulletin from the Ministry of finance and economic development (SL). We considered annual reports from World Bank, United Nations record books such as United Nations conference on trade and development (UNCTAD), published journals on the World Wide Web and other reliable international sources. The scope of the study as stated earlier is a thirty-seven years period starting from 1980 to 2016 inclusive. We used Graphs, tables, and charts to present and analyze data and where necessary we considered other tools as well.

\subsection{Model Specification}

We will first try to investigate the relationship between growth rate of GDP and growth rate of FDI using a graphical representation in establishing whether we have a relationship or not. If the growth rate of FDI is directly propositional to the growth rate of GDP, then we can conclude that FDI is determining the growth of GDP. Therefore, the growth rate of GDP is calculated at any given period (time- $t$ ) by the equation: 
Table 2. Trade development finance.

\begin{tabular}{ccccc}
\hline External Financing Inflows (mil. USD) & $\mathbf{2 0 0 6 / 0 8}$ & $\mathbf{2 0 1 2 / 1 4}$ & $\mathbf{2 0 1 5}$ & $\mathbf{\Delta : 0 6 / 0 8 - 1 5}$ \\
\hline FDI Inflows & 71.0 & 518.7 & 518.7 & $631 \%$ \\
Remittances & 26.7 & 65.5 & 66.2 & $148 \%$ \\
Other Official Flows (OOF) & 0.3 & 22.1 & 9.7 & $3241 \%$ \\
OOF of which are trade related & 0.0 & 18.8 & 0.0 & - \\
Official Development Assistance (ODA) & 736.6 & 633.8 & 1015.0 & $38 \%$ \\
ODA of which Aid for Trade & 54.0 & 101.6 & 65.4 & $21 \%$ \\
\hline
\end{tabular}

Source: unctadstat.unctad.org.

$$
\mathrm{GDP} \_g r=\left(\mathrm{GDP}-\mathrm{GDP}_{t-1}\right) / \mathrm{GDP}_{t-1}
$$

Moreover, the same technique is applied for the FDI variable and represented by the equation

$$
\text { FDI_gr }=\left(\text { FDI }-\mathrm{FDI}_{t-1}\right) / \mathrm{FDI}_{t-1}
$$

Based on results obtained on the relationship between the two variables, we will then conduct further statistical and regression analysis from the data available.

The model in this paper is estimated using data available on the following variables; gross domestic product (GDP), foreign direct investment (stock) inflow (FDI inflow), gross fixed capital formation (GFCF) and export (EXPT), and represented as follows:

GDP $=$ Foreign direct investment $\times$ export $\times$ Gross fixed capital formation

$$
\mathrm{GDP}=F(\text { FDI, EXPT, GFCF }) .
$$

In this case, GDP is the total GDP in currency at current prices. FDI is the total stock inward in currency at current prices; we considered stock inward because the country under study has little or no investment outside its borders under the 37 years considered. This mean, we are considering the total amount of investment that is coming into the country and not considering investments that short-down due to inability of investors to invest and withdrawing such investment in later years leading to net investment in some periods being negative. EXP is the total trade in goods and services as reported in the balance of payment accounts. Goods include general merchandise, non-monetary gold values; services are intangible transactions such as royalties, travels, and business services, etc. GFCF formally known as the gross domestic investment is spending on additions to fixed assets (plants and machinery, schools, hospitals and commercial and industrial buildings, etc.) of the economy and net changes in inventory levels (stock of goods held by firms in production, work in progress or sales).

To formalize the model we introduce an intercept (constant term) $\alpha$ and coefficients $\beta_{1}, \beta_{2}, \beta_{3}$ in the equation and also included an error term $\varepsilon$, these coefficients are expected to be greater than zero. 
Having reported the economic model in the multiplicative form, it is then linearization through logs as follow:

$$
\log \mathrm{GDP}=\alpha+\beta_{1} \log \mathrm{FDI}+\beta_{2} \log \mathrm{EXPT}+\beta_{3} \log \mathrm{GFCF}+\varepsilon
$$

From the above, we now formulate our regression equation in log form at time-t as follow:

$$
\log \operatorname{gdp}_{t}=\alpha+\beta_{1} \log \mathrm{fdi}_{t}+\beta_{2} \log \operatorname{expt}_{t}+\beta_{3} \log \text { gfcf }_{t}+\varepsilon_{t}
$$

The expected result from the empirical analysis is that FDI must have a positive relationship with economic growth in Sierra Leone, which means the null hypothesis here states that there is no relationship between the two variables. This hypothesis can be denied or confirmed base on results obtained from the regression analysis.

\subsection{Augmented Dickey-Fuller Test and Phillips-Perron Test}

In most regression analysis methods using time series data (such as the ordinary least square (OLS)), it is necessary that the variables are stationary. Stationary time series indicates that statistical properties of sample data (such as the mean and autocorrelation, etc.) are constant over time (I.e., Stationary means the data evolves around a constant means). In other to determine the relationship between GDP and FDI, it is necessary to know whether the variables are stationary or not. To tackle this problem, we will employ the unit root test in the Augmented Dickey-Fuller test (ADF test), which is an advanced form of the Dickey-Fuller test (1979) and also the Phillips-Perron test (PP test). The ADF test usually has three possible ways of using the model, and all of them yield the same result, in this case, we will use the regression model that uses the intercept method only (instead of the models with trend and intercept or model with no trend and no intercept).

Let suppose that $y_{t}=\alpha+\beta_{1} y_{t-1}+\cdots+\beta_{n} y_{t-n}+\varepsilon_{t}$ is an intercept form of an $\operatorname{AR}(n)$ model, where $y_{t}$ is the variable under consideration, $\alpha$ is the intercept, $\beta_{1}, \cdots, \beta_{n}$ is the coefficient of the variable, $t$ is any given time, $\mathrm{n}$ is number of lags, and $\varepsilon_{t}$ is the error term. Then the intercept form of the model under the unit root process of the ADF test will be as follows:

$\Delta y_{t}=\alpha+\beta_{1} y_{t-1}+\cdots+\beta_{n} \Delta y_{t-n}+\varepsilon_{t}$, where $\Delta$ is the differencing operator.

One might ask how many lags should we add for the variable to be stationary; actually, it turns out that we should continue adding lag terms until we have no serial correlation in our error term and in case by adding few more lags doesn't solve the problem, it is better not to add them. Under the ADF test, the null hypothesis $\left(H_{0}\right)$ state that we have a unit root test or the variable is not stationary and the alternate hypothesis $\left(H_{1}\right)$ state that the variable is stationary or doesn't have a unit root test. To determine whether we have a unit root or not, we should focus on the test statistic (t-stat) and compare it to the critical values of $1 \%, 5 \%$ and $10 \%$ (mostly, the $1 \%$ or $5 \%$ is recommended). If the $\mathrm{t}$-stat is higher than the critical values, we reject the null hypothesis and accept the alternate 
hypothesis, but if the t-stat is less than the critical values we accept the null hypothesis that the variable has a unit root or the series is not stationary. In case, at first sight, the variable is not stationary, we should apply the first differencing method by converting the variable using the first difference method to attain stationarity.

Usually, not all variables become stationary at first differencing, and if this happens, then we should apply the second differencing. In this paper, we are applying these two models to capture whether $\beta$ is significant or not;

$$
\Delta \log \mathrm{GDP}_{t}=\alpha+\Delta \log \beta \mathrm{FDI}_{t}+\varepsilon_{t}
$$

and

$$
\Delta \log \mathrm{GDP}_{t}=\alpha+\Delta \log \beta \mathrm{FDI}_{t-1}+\varepsilon_{t},
$$

The later model assumes a one year lag period. $\Delta \log \mathrm{GDP}_{t}$ and $\Delta \log \mathrm{FDI}_{t}$ and is calculated as follows: ( $\left.\Delta \log y_{t} \equiv \log y_{t}-\log y_{t-1}\right)$ at the base year and $\left(\Delta \log y_{t-1} \equiv \log y_{t-1}-\log y_{t-2}\right)$ at one year lag. From these two equations, we will check whether $\beta$ is significance or not.

The PP test is similar to the ADF test as it is also built on the Dickey-Fuller test in other to address the problem of high order autocorrelation. The PP test makes a non-parametric correction to $t$-stat and requires bandwidth parameters which tend to create a finite sample problem, as opposed to the associated lag lengths in $\mathrm{ADF}$ test that rely on parametric transformation. Basically, lags are omitted in the PP test in other to adjust standard error to correct autocorrelation and heteroskedasticity. The Phillip-Perron is thus similar to the ADF test and is specified as follow:

$$
\Delta y_{t}=\alpha+\beta_{1} y_{t-1}+\cdots+\beta_{n} \Delta y_{t-n}+\varepsilon_{t}
$$

In this paper, we are using E-views and Matrixer software to do the required calculations and estimations of models stated.

\section{Results and Discussion}

\subsection{Results of Unit Root Tests}

The ADF test and PP test are used to determine the stationarity of the variables. The result from Table 3 below shows the ADF test at level for both variables and indicates that the absolute critical values at all levels are greater than the absolute t-test statistic, which means we accept the null hypothesis that the variable is non-stationary. With a P-value of $93.64 \%$ for GDP, it means there is very high chance that there is an error in estimating the t-statistic value in the model, while for FDI there is a $99.35 \%$ of such error estimation.

With the first difference, we can see that the absolute t-statistic for log FDI is greater all it absolute critical values at all levels, and its $\mathrm{P}$-value is also significant. We can say that at the first differencing of log FDI, the series is now stationary. As for $\log$ GDP, the variable is stationary at both $1 \%$ and $10 \%$ absolute critical values. At the $5 \%$ critical value, its little bit complicated, although we have a $\mathrm{P}$-value of 0.051 level of significances. 
Table 3. Result for unit root test. Results from test of stationarity using Augmented Dickey-Fuller unit root Test.

\begin{tabular}{cccccc}
\hline \multicolumn{5}{c}{ Augmented Dickey-Fuller Test Statistics } \\
\hline variables & Level/ $\Delta$ level & Lag length ${ }^{* *}$ & t-statistic & Prob $^{*}$ & Inference \\
\hline \multirow{2}{*}{ Log GDP } & Level & 5 & -0.001 & 0.936 & Non-stationary \\
& $\Delta$ Level & 3 & $-0.029^{* * *}$ & 0.051 & stationary \\
\hline \multirow{2}{*}{$\log$ FDI } & Level & 2 & 0.852 & 0.994 & Non-stationary \\
& $\Delta$ Level & 1 & $-5.437^{* * * *}$ & 0.000 & stationary \\
\hline
\end{tabular}

Source: author's computation, 2018. Note: ${ }^{\star}$ Mackinnon (1996) one-sided p-value; ${ }^{\star *} \mathrm{Au}$ tomatically generated (based on AIC); ${ }^{* *}$ and ${ }^{* * * *}$ indicates the variable is stationary at the $1 \%$ and $5 \%$ level of critical values (significance) respectively and $\Delta$-first difference.

In the Phillip-Perron test shows in Table 4 below, the same null hypothesis is applied, that is the series is non-stationary at level. Note this test is a non-parametric. We can see that from the results obtained; we cannot reject the null hypothesis for series of both variables. The values for log GDP and log FDI is $88.84 \%$ and $95.86 \%$ respectively, and this means there is a high chance of getting an error in estimating the $t$-statistic value in the model. At the first differencing, both variables absolute $t$-statistics values are greater than their respective absolute critical values at all levels. From the results, we can now accept the alternative hypothesis that series for both variables are stationary.

\subsection{Results from OLS Regression}

Table 5 and Table 6 below shows the results obtain from Equations (5) and (6) indicate that the coefficient $\beta$ is insignificant with -0.042 and -0.042 respectively, which can thus support our previous conclusion that FDI has a negative relationship with economic growth. This result suggests that FDI can yield unintended negative results on economic growth due to weak, rigid policies.

Now we might be faced with the question, why there is a negative relationship between FDI and economic growth in Sierra Leone. In the context of empirical literature and theoretical models, different results have been attained by various researchers. Alfaro et al. (2006) [39] suggested in their conclusion that most empirical literature at both macro and micro level mostly indicates there is either no effect of FDI on a host country's aggregate growth or a completely negative effect. While on the other hand, theoretical model of FDI shows a positive effect on the economic growth of a country.

Most of the FDI in Sierra Leone is a result of MNEs seeking raw materials (backward vertical FDI). With country's rich mineral deposit, most of it FDI is concentrated in it primary sector (mining industry), similar result is also found by Khaliq A. and Noy I. (2007) [29], Sesay B. (2015) [38], Juma M. (2012) [40] stated that most positive result of FDI in Africa is found in mineral-poor countries and not their counterparts mineral-rich countries. 
Table 4. Result for unit root test. Results from Test of Stationarity Using Phillip-Parron Unit Root Test.

\begin{tabular}{cccccc}
\hline \multicolumn{5}{c}{ Phillip-Perron Test Statistics } \\
\hline variables & Level/ $\Delta$ Level & Bandwidth $^{\star *}$ & Adj. t-statistic & Prob $^{\star}$ & Inference \\
\hline \multirow{2}{*}{ Log GDP } & Level & 1 & -0.456 & 0.888 & Non-stationary \\
& $\Delta$ Level & 3 & -5.136 & 0.000 & stationary \\
\hline \multirow{2}{*}{$\log$ FDI } & Level & 3 & 0.067 & 0.9586 & Non-stationary \\
& $\Delta$ Level & 1 & -8.829 & 0.000 & stationary \\
\hline
\end{tabular}

Source: author's computation (e-views), 2018. Note: ${ }^{\star}$ Mackinnon (1996) one-sided p-value; ${ }^{\star *}$ (Newey-west automatic) using Bartlett Karnel; ${ }^{\star * \star}$ and ${ }^{\star * * \star}$ indicates the variable is stationary at the $1 \%$ and $5 \%$ level of critical values (significance) and $\Delta$-first difference.

Table 5. Results from OLS regression.

\begin{tabular}{|c|c|c|c|c|}
\hline \multicolumn{5}{|c|}{ Dependent Variable: $\Delta \log$ GDP } \\
\hline \multicolumn{5}{|c|}{ Method: Least Squares } \\
\hline \multicolumn{5}{|c|}{ Sample (adjusted): 19812016} \\
\hline \multicolumn{5}{|c|}{ Included observations: 36 after adjustments } \\
\hline \multicolumn{5}{|c|}{ Independent Variable: $\Delta$ log FDI (base year) } \\
\hline Variable & Coefficient & Std. Error & $\mathrm{t}-$ Statistic & Prob. \\
\hline$\Delta \log$ FDI & -0.041753 & 0.086563 & -0.482339 & 0.6327 \\
\hline Constant & 0.030343 & 0.03017 & 1.005733 & 0.3216 \\
\hline R-squared & 0.006796 & & & \\
\hline Adjusted R-squared & -0.022416 & & & \\
\hline
\end{tabular}

Source: author's computation (e-views), 2018.

Table 6. Results from OLS regression.

\begin{tabular}{|c|c|c|c|c|}
\hline \multicolumn{5}{|c|}{ Dependent Variable: $\Delta \log$ GDP } \\
\hline \multicolumn{5}{|c|}{ Method: Least Squares } \\
\hline \multicolumn{5}{|c|}{ Included observations: 35 after adjustments } \\
\hline \multicolumn{5}{|c|}{ Independent Variable: $\Delta \log$ FDI(one year lag) } \\
\hline Variable & Coefficient & Std. Error & $\mathrm{t}-$ Statistic & Prob. \\
\hline$\Delta \log \mathrm{FDI}(-1)$ & -0.041677 & 0.052357 & -0.796015 & 0.4317 \\
\hline Constant & 0.027299 & 0.030501 & 0.895024 & 0.3773 \\
\hline R-squared & 0.018839 & & & \\
\hline Adjusted R-squared & -0.010893 & & & \\
\hline
\end{tabular}

Source: author's computation (e-views), 2018. 
As suggested by Borensztain et al. (1998) [41], the educational and human capital level of a country plays a vital role in connecting FDI and economic growth. In recent years, with various political instabilities, displacement and destruction of schools and learning facilities (during the civil war), the country's workforce have been destabilized resulting to lost skilled labor and competent managerial workforce. Much has been done to improve the educational sector by various governments since the end of the civil war. Another major factor from our finding is that the country lack well developed financial market which can bridge the linkage between domestic and foreign investment from positive spillover to the entire economy as a whole [42]. From observations, the country experienced negative net-flows of FDI in various years under the period considered for this research, this can also be a reason negative impact, and this result is supported by Abbas Q. et al. (2011) [43] as well. With regards statistical data, this result is not surprising, because we can see that the industrial sector is the least contributing sector to GDP over the years.

\section{Conclusions}

The paper aims to investigate the impact of FDI (stock) inflow on economic growth in Sierra Leone. Since gaining independence in 1961 from Britain, the country has been struggling with both natural and man-made disasters including a deadly civil war in the 1990s that lasted for over a decade, political instability and socio-economic problems. The country is mostly dependent on foreign aid to support its budget deficits, although it has a vast deposit of mineral resources such as diamond, iron ore, gold, bauxite, fertile land for agricultural purpose and tourist attraction centers.

In this paper we considered a thirty-seven-year period (1980-2016), the country's vast deposit and exploration of its mineral resources paved the way for the research problem. We considered data from the World Bank, Bank of Sierra Leone and UNCTAD statistical database, etc. We applied a linear regression model for statistical analysis and used the Augmented Dickey-Fuller test and Phillip-Perron test to test for stationarity of the variables.

From results obtained, it was found that there was no relationship between FDI and economic growth during the period considered. This result is not usual. Most of the investment that comes into the country is concentrated to its richmining sector in the form of backward vertical FDI with no value addition before being exported. The weak educational structure and level of human capital in the country to accommodate spillover in managerial knowledge, technological and production processes can be seen as some of the setbacks for FDI to an impact on economic growth in the country. The political and socio-economic instability in the country during the period considered is a major factor which prevented it from creating a platform to develop well-structured financial markets system that can bridge the linkage between financial institutions, domestic and foreign investment. Another major issue is the country inability to retain the 
FDI coming in which later results to negative net flow especially in relation to the countries balance of payment.

In conclusion, the purpose of this paper was to investigate the impact of FDI on economic growth by first considering the relationship between FDI and economic growth in Sierra Leone. Despite some of the limitations encountered, we ascertained that there is no relationship between the two variables which are based on models considered; the study is also in line with previous results, especially for rich-mineral African countries.

\section{Conflicts of Interest}

The authors declare no conflicts of interest regarding the publication of this paper.

\section{References}

[1] Okeke, R.C., Ezeabasili, V.N. and Nwakoby, C.N.I. (2014) Foreign Direct Investment and Economic Growth in Nigeria: An Empirical Evidence. International Journal of Innovative Research in Management, 3, 30-39.

[2] Duramany-Lakkoh, E.K. (2020) The Effect of Fiscal Policy on Financial Sector Development in Sierra Leone: A Time Series Approach. International Journal of Development and Economic Sustainability, 8, 1-23.

[3] Duramany-Lakkoh, E.K. (2021) A Foreign Aid and Economics Development Nexus: The Case of Sierra Leone: Foreign Aid in Sierra Leone, Economic Development in Sierra Leone, Archives of Business Research, 9, 219-233.

[4] Bermúdez-Lugo, O. (2016) The Mineral Industry of Sierra Leone. U.S. Geological Survey Minerals Yearbook-2013. USGS Science for a Changing World. https://s3-us-west-2.amazonaws.com/prd-wret/assets/palladium/production/minera 1-pubs/country/2013/myb3-2013-sl.pdf

[5] International Monetary Fund (2005) Balance of Payments Manual. 5th Edition, IMF, Washington DC.

https://www.imf.org/en/Publications/Books/Issues/2016/12/30/Balance-of-Payment s-Manual-157

[6] Organisation for Economic Co-Operation and Development (1996) OEDC Benchmark Definition of Foreign Direct Investment. 3rd Edition, OEDC, Paris. https://www.oecd.org/daf/inv/investment-policy/2090148.pdf

[7] Vernon, R. (1979) The Product Cycle Hypothesis in a New International Environment. Oxford Bulletin of Economics and Statistics, 41, 255-267.

https://doi.org/10.1111/j.1468-0084.1979.mp41004002.x

[8] Soubbotina, T.P. (2004) Beyond Economic Growth: An Introduction to Sustainable Development. 2nd Edition, World Bank, Washington DC. https://openknowledge.worldbank.org/handle/10986/14865 https://doi.org/10.1596/0-8213-5933-9

[9] Domar, E.D. (1946) Capital Expansion, Rate of Growth, and Employment. Econometrica, 14, 137-147. https://doi.org/10.2307/1905364

[10] Piętak, L. (2014) Review of Theories and Models of Economic Growth. Comparative Economic Research, 17, 45-60. https://doi.org/10.2478/cer-2014-0003

[11] Heinz, D.K. and Neri, S. (2014) Revisiting Classical Economics, Studies in LongPeriod Analysis. Routledge, London.

[12] Richardo, D. (1951) On the Principles of Political Economics and Taxation Vol. I. 
Cambridge University Press, Cambridge.

[13] Malthurs, T.R. (1925) Prawo Ludnosci, Warszawa. In: Malthus, T.R., Ed., An Essay on the Principles of Population, Macmillan, London.

[14] Max, K. (1938) Capital: A Critique of Political Economy (Volume I). Progress Publishers, Moscow.

https://www.marxists.org/archive/marx/works/download/pdf/Capital-Volume-I.pdf

[15] Schumpeter, J.A. (1934) The Theory of Economic Development: An Inquiry into Profits, Capital, Credits, Interest, and the Business Cycle. Transaction Publishers, Piscataway.

[16] Rostow, W.W. (1960) The Stages of Economic Growth: A Non-Communist Manifesto. Cambridge University Press, Cambridge.

[17] Vo, X.V. and Batten, J.A. (2006) The Importance of Social Factors When Assessing the Impact of Foreign Direct Investment on Economic Growth. Institute for International Integration Studies. IIIS Discussion Paper No. 179.

https://doi.org/10.2139/ssrn.945151 https://www.tcd.ie/triss/assets/PDFs/iiis/iiisdp179.pdf

[18] Mohammaed, A.A. and Mahmoud, K.A. (2013) Foreign Direct Investment and Economic Growth Literature Review from 1994 to 2012. Procedia-Social and Behavioural Science, 129, 206-213. https://doi.org/10.1016/j.sbspro.2014.03.668

[19] Duramany-Lakkoh, E.K., Jalloh, M.S. and Jalloh, A. (2021) Foreign Direct Investment and Manufacturing Sector in Sierra Leone: A Vector Auto-Regression Analysis Approach. Journal of Mathematical Finance, 11, 620-650. https://doi.org/10.4236/jmf.2021.114034

[20] Elboiashi, H.A. (2011) The Effect of Foreign Direct Investment and Other Foreign Capital Inflow on Growth and Investment in Developing Country. Ph.D. Thesis, Department of Economics, University of Glasgow, Glasgow. https://theses.gla.ac.uk/3026/1/2011elboiashiphd.pdf

[21] Landry, C. (2015) The Impact of Foreign Direct Investment on the Economic Growth of Cameroon. Master's Thesis, Institute of Graduate Studies and Research, Eastern Mediterranean University, Gazimağusa.

[22] Semwanga, J.P. (2011) Foreign Direct Investment and Economic Growth: The Case of Uganda (1970-2007) Master's Thesis, Makerere University, Kampala. http://makir.mak.ac.ug/bitstream/handle/10570/2364/semwanga-cobams-masters.p df\%3Bjsessionid\%3D049A171D4E519ED8B6D78BAA2A218662? sequence\%3D3

[23] Ovat, O.O. and Antakikam, A.E. (2018) Foreign Direct Investment And Economic Growth in Developing Countries: How Has Nigeria Fared. IOSR Journal of Economics and Finance, 9, 55-63.

[24] Adeleke, K.M., Olowe, S.O. and Fasesin, O.O. (2014) Impact of Foreign Direct Investment on Nigeria Economic Growth. International Journal of Academic Research in Business and Social Sciences, 4, 234-242.

[25] Nigh, D. (1986) Political Event and Foreign Direct Investment Decision: An Empirical Examination. Management Decision Economics, 7, 99-106. https://doi.org/10.1002/mde.4090070205

[26] Mohnen, P. (2001) International R\&D Spillovers and Economic Growth. In: Pohjola, M., Ed., Information Technology, Productivity and Economic Growth, Oxford University Press, New York, 50-71.

https://doi.org/10.1093/acprof:oso/9780199243983.003.0003

[27] Wang, M. (2009) Manufacturing FDI and Economic Growth: Evidence from Asian 
Economies. Applied Economics, 41, 991-1002. https://doi.org/10.1080/00036840601019059

[28] Gui-Diby, S.L. (2014) Impact of Foreign Direct Investment on Economic Growth in Africa: Evidence from Three Decades of Panel Data Analyses. Research in Economics, 68, 248-256. https://doi.org/10.1016/j.rie.2014.04.003

[29] Khaliq, A. and Noy, I. (2007) Foreign Direct Investment and Economic Growth: Empirical Evidence from Sectoral Date in Indonesia. Working Paper, Department of Economics, University of Hawaii at Manoa, Honolulu. https://economics.hawaii.edu/research/workingpapers/WP 07-26.pdf

[30] Adewumi, S. (2016) The Impact of FDI on Economic Growth in Developing Countries: An African Experience. Master's Thesis, Jönköping University, Jönköping. https://www.diva-portal.org/smash/get/diva2:4440/FULLTEXT01.pdf

[31] Akinlo, A.E. (2004) Foreign Direct Investment and Economic Growth in Nigeria: An Empirical Investigation. Journal of Policy Modelling, 26, 627-639. https://doi.org/10.1016/j.jpolmod.2004.04.011

[32] Chabe, L. (2015) The Impact of Foreign Direct Investment on the Economic Growth of Cameroon. Master's Thesis, Eastern Mediterranean University, Gazimağusa. http://i-rep.emu.edu.tr:8080/jspui/bitstream/11129/2545/1/ChabeLandry.pdf

[33] Bangura, A. (2010) Sierra Leone Economic Records 1961-2010. Ministry of Finance and Economic Development.

https://www.theigc.org/wp-content/uploads/2014/08/Alimamy-Bangura-Sierra-Leo nes-economic-record.pdf

[34] World Integrated Trade Solutions (2017) Sierra Leone Trade Indicators. https://wits.worldbank.org/CountryProfile/en/Country/SLE/Year/2017

[35] World Bank Group (2017) World Development Indicators 2017. https://openknowledge.worldbank.org/handle/10986/26447

[36] World Bank Group (2017) Doing Business Report: Measuring Business Regulations. https://www.doingbusiness.org/en/reports/global-reports/doing-business-2017

[37] African Economic Outlook (2017) Entrepreneurship and Industrialisation. https://www.oecd.org/dev/african-economic-outlook-19991029.htm

[38] Brima, S. (2015) Macroeconomic Determinants of Foreign Direct Investment in Sierra Leone: An Empirical Analysis. International Journal of Economics and Finance, 7, 123-133.

[39] Alfaro, L., Chanda, A., Kalemli-Ozcan, S. and Sayek, S. (2006) How Does Foreign Direct Investment Promote Economic Growth? Exploring the Effects of Financial Markets on Linkages. NBER Working Paper 12522.

[40] Juma, M.A. (2012) The Effect of Foreign Direct Investment on Growth in Sub-Saharan Africa. Amherst College, Amherst.

https://www.amherst.edu/media/view/434456/original/Juma,\%20Mary-Ann\%20The sis.pdf

[41] Borensztein, E., Gregorio, J. and Lee, J.W. (1998) How Does Foreign Direct Investment Affect Economic Growth? Journal of International Economics, 45, 115-135. https://doi.org/10.1016/S0022-1996(97)00033-0

[42] Alfaro, L., Chanda, A., Kalemli-Ozcan, S. and Sayek, S. (2004) FDI and Economic Growth: The Role of Local Financial Markets. Journal of International Economics, 64, 89-112. https://doi.org/10.1016/S0022-1996(03)00081-3

[43] Abbas, Q., Salman, A., Nasir, A. S., Ullah, H.A. and Naseem, M.A. (2011) Impact of Foreign Direct Investment on Gross Domestic Product. Global Journal of Management and Business Research, 11, 34-40. 